\title{
The Effect of Risk Management Practices on Performance of Small and Medium Scale Enterprises
}

\author{
Sidney Apaloo (Postgraduate) \\ Department of Financial Science of the School of Business and Economics, Presbyterian \\ University College. E-mail: sidney.apaloo@gmail.com \\ Dzah Bright, CA, MSc, BSc (Corresponding author) \\ Independent Researcher, Best Brain Consult \\ E-mail: dzahbright@gmail.com
}

Received: December 1, 2021

Accepted: January 23, 2022 Published: January 28, 2022

doi: 10.5296/erm.v7i1.19287

URL: https://doi.org/10.5296/erm.v7i1.19287

\begin{abstract}
The main objective of the research is to examine the effect of risk management practices on performance of Small and Medium Scale Enterprises (SMEs). The convenience sampling method was used for the study. The study used a sample size of 285 small and medium scale enterprise businesses for the analysis. The study used primary data obtained through questionnaire administration which was analysed using SPSS 25 and Microsoft Excel 2019. The study used both descriptive and inference analysis to analyse the data. According to the findings, low educational level of respondents helped to conclude that risk management is not widely practiced in SME businesses. Risk management practices are not well practiced in SME business because the SME owners possess low level of knowledge in the areas of identifying, assessing, treating and monitoring key operational risks. The positive relationship between risk management practices and performance is indicative that the proper practice of risk management by SME managers or owners influences performance. The significant relationship between the dependent variable (performance) and independent (risk management practices) provided the conclusion that, the more SME businesses improve on their risk management, the more they improve upon their performance. The study recommends an improvement in risk management knowledge for SME business owners and managers. The government should take adequate steps to provide risk management support for SMEs sectors. The study recommends SME businesses to put in place systems that enable
\end{abstract}


the documentation of the business operations.

Keywords: risk management, risk process, risk decisions, SME performance

\section{Introduction}

Small and Medium Scale Enterprises (SMEs) are the foundations of economic growth of most nations due to their immense contribution to social-economic growth and development of these countries. The growing importance of SMEs predominant in developing countries has attracted the attention of academician and policyholders in evaluating the potential that SMEs have on the national economy. According to Ferreira et al. (2019), the informal sector which is the largest in most developing countries like Ghana is dominated by SMEs. Simota, Tupa \& Steiner (2018) posit that the role of SMEs is evident in their ability to create employment, alleviate poverty especially among the venerable group in society (women and children), improve standard of living, enhance innovation, lead to equitable income distribution and help in developing entrepreneurial skills. A study conducted by the Small and Medium Enterprises Development Agency of Nigeria (SMEDAN) (2013) revealed that the over 37 million SMEs that exist in Nigeria creates employment for more than $80 \%$ of the population. Eyiah (2015) argues that majority of jobs in Ghanaian economy are created by the SMEs. Likewise, SMEs play significant role in developed economies (i.e., USA, Australia, UK, Malaysia, China). According to the Malaysia Department of Statistics, the contributions of SMEs has led to the increase in the Gross Domestic Product of the country by $0.5 \%$ and the Economic Census of 2016 discovered that the SME business establishment in Malaysia recorded a significant statistic of $98.5 \%$ or 907,065 SMEs, which shows that a lot of people are getting into the SMEs space even in developed countries (Yakob et al., 2019).

An SME according to Ghana Statistical Service (2010) is an enterprise or business venture that employs below one hundred employees with a total capital employed not exceeding 10 million Ghana cedis. Eyiah, (2015) therefore posit that SMEs normally have a staff strength of 9-100 people working with the employer. Most business owners of SMEs perform all the core functions of the business with respect to finance, management, operations among others and major decisions are taken by them to ensure the successful running of the business. Since risk is a potential part of every business in ensuring their survival or otherwise, the level of risk management by SMEs is critical to their survival and sustainability (Yakob et al., 2019).

There are numerous risks faced by SMEs that have reduced their lifespan and led to a shorter tenure of their existence in the market (Belás et al., 2015). Yusuf and Dansu (2013) highlighted that majority of SMEs established in developing countries do not last for a long time, which means that only a small number of SMEs remain in the market place for more than five years. In the case of Nigeria, there is evidence pointing to the fact that most SMEs do not survive their first five years of establishment (Eniola, Entenbang \& Sakariyau, 2015). Specifically, $80 \%$ to $85 \%$ of them fail before their fifth anniversary while another $10 \%$ to 15\% die before reaching 10 years (Eniola, Entenbang \& Sakariyau, 2015; Agwu \& Emeti, 2014). Likewise, in Ghana, Eyiah (2015) found similar evidence to also conclude that majority of SMEs do not last in the marketplace. The factors militating against the survival of SMEs seem to be embedded in the various risks hindering small scale businesses from 
growing and surviving in the marketplace as a result of poor or no risk management culture existing in these SMEs (Crovini, Santoro \& Ossola, 2020). The poor approach to risk management by SMEs weakens their performance and overall profitability as well as their competitiveness and survival (Adeyele \& Osemene, 2018).

\subsection{The Problem Statement}

There has always been a lack of guidance for SME businesses on how best to manage risk or where to seek advice from on the management of the risk that their businesses face. To make matters worse, most SMEs usually have limited resources, inflexible procedures and lack of knowledge when it comes to risk management (Santoro et al., 2019). Many SMEs in developing countries like Ghana have not put in place risk management procedures to properly manage the business risks that their organizations face. According to Crovini, Santoro \& Ossola (2020), most SME owners lack knowledge in risk management and do not have any proper training with respect to same. Juxtaposing, the immense contribution of SMEs in both developed and developing nations against the challenges facing SMEs in the area of risk management that is a threat to their existence, the logical conclusion is to adopt and implement risk management procedures to help SMEs better deal with the issue of risk and also improve SME profitability (Florio \& Leoni, 2017).

The review of literature in the field of study revealed that most empirical evidence on risk management in SMEs comes from the developed countries such as USA, UK, Australia and Malaysia (Li et al., 2014, Belás et al., 2015; Yakob et al., 2019; Crovini, Santoro \& Ossola, 2020). There seems to be lack of evidence from emerging and developing economies like Ghana. Other studies in the sub-region were studies carried out in Nigeria (Yusuf \& Dansu, 2013; Agwu \& Emeti, 2014, Adeyele \& Osemene, 2018). There is, therefore, no evidence to show that research on risk management practices of SMEs in Ghana as a developing country has produced any empirical data. This leaves a major gap in literature relating to risk management in Ghanaian SMEs which need to be supplemented. This study therefore seeks to examine the effect of risk management practice on profitability of SMEs. The outcome of the study will reveal the potentials of risk management implementation in reducing the failure rate of Small and Medium Scale Enterprises (SMEs). Also, the study will provide literature on risk management with regard to Ghanaian SMEs, which will be achieved by reviewing existing debates, drawing attention to new thinking about risk management focused on SMEs while highlighting recent innovations and efforts to improve the SME sector through the adoption of appropriate risk management procedures.

The following section discusses the literature review, methodology, data analysis and discussions, and conclusion the study.

\section{Literature Review}

\subsection{Overview of Small and Medium Sizes Enterprises}

According to Sax and Torp (2015), SMEs are the non-subsidiary and self-governing firms which employ less than a given number of employees. By focusing on the number of staff and turnover, Meidell and Kaarbøe (2017), identifies small or medium-sized enterprises as 
firms with less than 100 employees and a turnover of less than EUR 15 million. Likewise, the European Commission (1996) adopted the concept of SMEs as firms with fewer than 250 employees, has an annual revenue of EUR 40 million and a net asset of EUR 27 million (Abor \& Adjasi, 2007). A number of researchers tend to define SMEs as having 0-250 employees and in Africa this number is set around the 200 mark (Ayagari, 2005). However, in the United States, SMEs comprise of firms with fewer than 500 employees (OECD, 2005). Most definitions of SMEs are based on size and number of employees, financial position or annual turnover.

\subsection{Risks in SMEs}

SMEs like any other business are faced with risks which cut across different areas of their operations. Risk to SMEs may fall into any of the following categories but not limited to financial risk, operational risk, growth risk, manufacturing risk, market risk (Aduko, 2011; Afolabi, 2018). Unfortunately, SMEs have always lacked guidance about how best to handle risk or where to obtain advice on risk they face and they typically have limited funds, inefficient processes and a lack of skills in managing their risks (Santoro et al., 2019). This phenomenon according to Ariyo (2008) has affected the performance and cashflow of SMEs firms as well as their survival. Azende (2012) stressed that SMEs are exposed to cash flow, consumer loss, marketing, physical (including natural disasters), competitive and finance-related risks which has become a barrier in the improvement of SME performance.

The lack of proper identification of risk in SME business compared to medium scale and big corporations according to Boniface and Ibe (2012) has become a challenge in SME business that needs be addressed. Kinyua et al (2015) posit that 70 percent of SMEs are unable to last for a long period of time in the marketplace because they lack the ability to manage the risk that threatens the survival of the businesses. In other words, studies have shown that only very few SMEs remain variable pass the 5 years period mark which is indicative that majority of SME businesses collapse before their 5th year anniversary (Owduri, 2012; Belás et al, 2014; Afolabi, 2018). Therefore, to ensure business sustainability of SMEs, there is the need for SME owners and managers to develop the ability to correctly identify risks and take appropriate risk management steps to cure the risk (Kagwathi et al, 2014).

\subsection{Risk Management in SMEs}

The business environment, of both small and major businesses, is changing due increasing competitiveness in the market place. To tackle these threats, businesses need to aim for high quality in both service and product delivery to meet the needs of consumers and to be well placed in the industry (Alrashidi and Bakeel, 2012). To do that, every business must have a solid understanding of its own company and its strengths, weaknesses, threats and opportunities. This should allow for risk to be predicted, measured and controlled in order for the business to stay competitive in the market place (Maseko and Manyani, 2011). According to research, risk affects the efficient and effective running of an organization and the magnitude of risks faced by SMEs often times force them out of business (Belás et al., 2015; Crovini, Santoro \& Ossola, 2020). 
Risk management has the potential to reduce the impact of the risk on business loss because in terms of risk exposure; small and medium-sized businesses are more vulnerable to it than large corporations, so they should be more interested in risk management (Ansong, 2013). Ansong (2013) also strongly advised that risk management be introduced because of its positive effect on the financial performance of SMEs. The review of literature has shown evidence that there exists a correlation between risk management and performance (Ansong, 2013; Gatzert and Martin, 2015; Meidell and Kaarbøe, 2017).

Particularly in Ghana studies have indicated that risk management increases access to credit facilities for SMEs and ultimately improves financial performance. (Tagoe, Nyarko and Anuwa-Amarh, 2005 as cited from Ansong, 2013). Meanwhile, Alrashidi and Baakeel (2012) find that operational risk management has positively affected SME financial growth and development. Therefore, risk management is a helpful technique that SMEs should follow to boost their chances of sustained and productive success, a concept frequently associated with large companies as a corporate governance necessity (Panigrahi, 2012)

\subsection{Empirical Review}

According to empirical evidence, Hafzuddin-Syah and Rubayah (2019), researched the effect of enterprise risk management practice on SME performance. Results from multiple regression analysis show that ERM has a positive and significant association with SME performance. Chiara et al (2019) researched on Rethinking risk management in entrepreneurial SMEs. The purpose of the study is to analyse the management of risk. The study adopted a multiple case study research design. The findings revealed that the risk management process cannot be always formalized but an unconscious risk analysis is always carried out. The study also determined that risk is an integral part of the decisions entrepreneurial oriented SME owners. The Influence of risk assessment on performance of SMEs in Kenya by Peninnah (2018) also revealed that risk assessment is a critical aspect of the risk management process and that is why most SME managers fail to properly assess the risk that is facing their organization. Aforlabi and James (2018) research on risk management and performance of small and medium scale enterprises in Nigeria focusing on $340 \mathrm{SME}$ operators in the Osun State of Nigeria. The study employed the linear regression to analyse the data which revealed a significant relationship between risk management and SME performance. The result further showed that attitude to risk positively affects risk management practices and that there is a strong positive correlation between risk identification and risk management.

\subsection{Conceptual Framework}

The conceptual framework of this study demonstrates the various components of the risk management process and how it influences operational risk management 


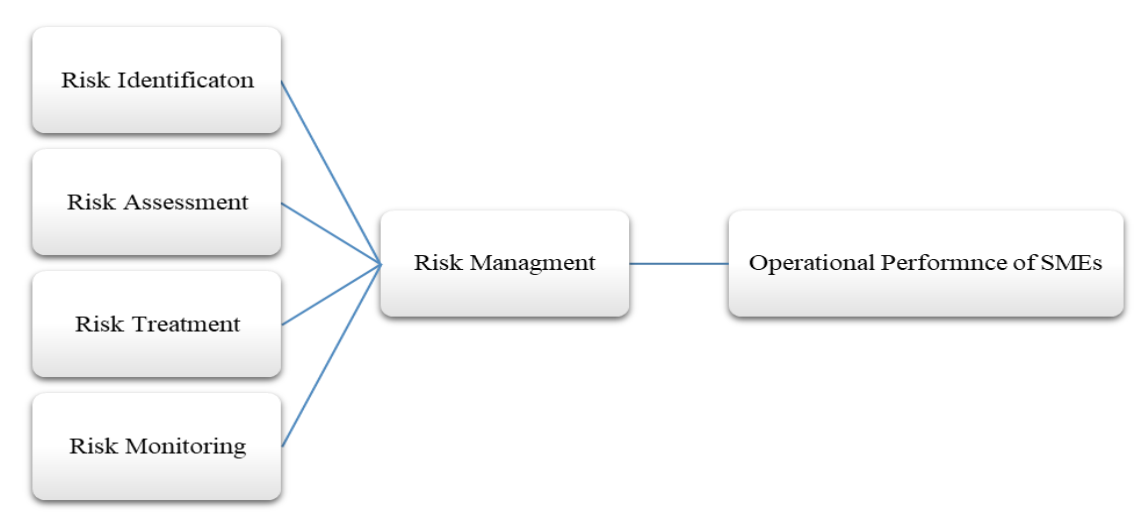

Figure 2.1: Conceptual Framework

\section{Method}

\subsection{Research Design}

According to Pallant, (2011), descriptive survey design involves collecting data which can then be used to answer the research questions in the current state. A quantitative research approach was used for this particular study. The primary purpose of the quantitative research is aimed at presenting a comprehensive analysis of the research problem (Creswell, 2014).

\subsection{Population}

For this study, SMEs businesses is defined to include small scale traders, small manufacturers, craftsmen, individual professionals and many small-scale businesses. The population of the study is SME businesses that are located in the Accra Metropolis which consists of all micro and small-scale enterprises in the Accra Metropolis and there are approximately 1000 micro and small-scale business found in this area.

\subsection{Sample Size and Sampling Procedures}

In this study, the convenience and purposive sampling were utilized to collect data. Convenience sampling is a non-probability sampling technique that helps the research to select his respondent more easily in terms of their location and time taken (Saunders, Lewis $\&$ Thornhill, 2012). The purposive sampling helps to select respondent that have the requisite knowledge on running SME business (Clark, 2016). To get a representation of respondents, the sample size is calculated using Yamane (1967) sample size determination formula. Based on Yamane (1967) formula, a sample size of 285 respondents was representative based out of a population of 1000 SME businesses. The two hundred and eighty-five SME managers/operators who have been operating for more than two years were targeted in this study.

\subsection{Model Specification}

Based on the objectives, the study employed the SME performance model to examine the impact of risk management on SME performance using the risk management strategies (risk identification, risk assessment, risk response and risk monitoring) as the independent 
variables and SME Performance as the dependent variable.

The multiple linear regression model was used for the study;

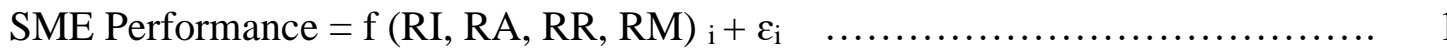

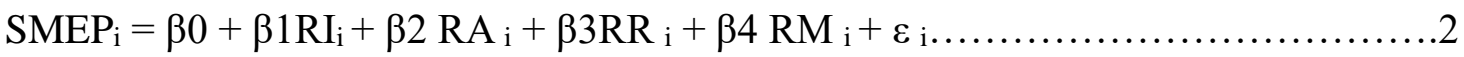

Where, SMEP is SME Performance, RI is Risk Identification, RA is Risk Assessment, RR is Risk Response, RM is Risk Monitoring, $\beta 0, \beta 1, \beta 2, \beta 3, \beta 4>0$ and are estimated coefficient of the independent variables and $\varepsilon t=$ Residual for the long run equation (error term)

\subsection{Reliability and Validity of Data}

According to literature, a Cronbach's alpha 0.7 is enough to confirm whether variables are reliable (Sekaran \& Bougie, 2009; Hair et al., 2009) The Cronbach alpha value for the instruments used is 0.861 as seen in Table 3.1, which is above 0.5 and 0.7 , therefore instrument is reliable.

Table 3.1: Cronbach's Alpha

\begin{tabular}{|l|l|}
\hline \multicolumn{2}{|c|}{ Reliability Statistics } \\
\hline Cronbach's Alpha & $\mathbf{0 . 8 6 1}$ \\
\hline N of Items & $\mathbf{3 2}$ \\
\hline
\end{tabular}

\section{Data Analysis and Results}

\subsection{Descriptive Analysis}

The study reveals that out of 285 respondents, $49 \%$ of them were females while $51 \%$ were males. The analysis revealed that $72(25 \%)$ do not have formal education, 151(53\%) have their basic and secondary education while $42(15 \%)$ of the respondents have technical/ vocational education and only $20(7 \%)$ out of the total of 285 respondents have tertiary education. Evidence from the analysis showed that majority of the respondents represented by $96(34 \%)$ provide services such as barbering, secretarial services and fitting services. Also, $84(30 \%)$ of the respondents are into retail which includes running of small shops like selling provisions, and electrical products while $37(13 \%)$ are involved in manufacturing of products such as shoemaking, tailoring etc. $39(14 \%)$ of the respondents are into a construction-related business which includes steel bending, carpentry, plumbing and masonry. 21(7\%) are involved in crop and animal farming activities while the rest $8(3 \%)$ are into fabrication business.

The result as presented in table 4.1 shows the descriptive statistics SME performance. The level of assessment of SME performance was done using 5-point Likert scale from strongly disagree through to strongly agree. The overall mean value was compared with the individual 


\section{Macrothink}

item means. The result shows the overall mean score $[\mathrm{M}=4.052]$. The findings indicate that all individual items obtained a mean score [ $>$ or $=4.052]$ and this shows a moderate level of acceptance that risk management improves performance of SME business in terms of their cashflow, sales revenue and growth as well as their overall profitability (Idemobi, 2012).

\section{Table 4.1: SME Performance}

\begin{tabular}{lcc}
\hline & $\mathrm{N}$ & MeanSD \\
\hline $\begin{array}{l}\text { Does proper risk management increase sales revenue levels } \\
\text { Does proper risk management improve year on year sale growth of the }\end{array}$ & 2854.051 .122 \\
business & 2854.011 .122 \\
Does proper management of risk increase the business cashflow & 2854.141 .141 \\
Does risk management improve the overall profitably of the business & 4.052 \\
Overall Mean & \\
\hline
\end{tabular}

\subsection{Knowledge of SME Owners on Risk Exposure}

The first step of an effective risk management is the ability and the skill to recognize the presence of risk (Eniola et al, 2015). Risk can only be identified if there is knowledge or an indication about the existence or presence of that risk. According to the study finding, majority of respondents $166(58 \%)$ are not sure whether or not their business is exposed to risk. $96(34 \%)$ of the respondents were not aware of the risk their businesses faces while $23(8 \%)$ have a level of knowledge about the risks their businesses are exposed to. Eniola et al (2015) argued that risk identification is the basis of any risk management strategy.

Table 4.2: Knowledge on Risk Exposure

\begin{tabular}{lllll}
\hline & Yes & No & No Sure & Total \\
& & & & \\
\hline $\begin{array}{l}\text { Do you know that your business is } \\
\text { exposed to risk? }\end{array}$ & 23 & 96 & 166 & 285 \\
& $8.1 \%$ & $33.7 \%$ & $58.2 \%$ & $100 \%$ \\
\hline
\end{tabular}

From Table 4.3 below, the findings of the study revealed that generally SME businesses do not have adequate knowledge about their risk levels as evident in the means values of the individual variables. The mean values were below the sample average which is a clear indication that respondents (SME owners and managers) have very little knowledge about the risks they face in their businesses.

The researcher asked respondents if they can properly identify risks that are affecting their 
business and the mean value of 2.09 ( $\mathrm{Std}=1.417$ ), is indicative that they cannot properly identify risks that their SME businesses face on daily basis. According to Agwu \& Emeti (2014), identification of risk is one of the most important areas with regards to managing risk. Failure to identify risk will certainly mean that no action is taken to manage that risk. The mean value of 2.35 (std 1.537) showed that SME business owners seem not to consider risk management as critical aspect of their business and as such have not placed risk management in the category of strategy issues that needed the attention of management. In addition, respondents fail to access any formal training or course about risk management (mean=1.98, $\mathrm{std}=1.091$ ). This indicates that most SME owners and SME businesses have zero or minimal knowledge about risk and its effect on their operations as a whole. Muhammad \& Amber (2011) argued that the level of knowledge of risk correlates with the measures one will take to reduce its impact on an activity. Bilal et al (2012) and Li et al (2014) point out that low levels of knowledge in the area of risk identification is normally underlined by low level of trainings. The Li et al (2014) pointed out that knowledge about the particular risk an organization faces drives their risk management strategy.

\section{Table 4.3: Risk Knowledge}

\begin{tabular}{|c|c|c|c|c|c|}
\hline & $\mathbf{N}$ & Min & Max & Mean & Std. D. \\
\hline $\begin{array}{l}\text { Can you properly identify risk that are affecting } \\
\text { your business operations }\end{array}$ & 285 & 1 & 5 & 2.09 & 1.417 \\
\hline $\begin{array}{l}\text { Do you consider managing risk a critical aspect of } \\
\text { the business }\end{array}$ & 285 & 1 & 5 & 2.35 & 1.537 \\
\hline $\begin{array}{l}\text { Have you taken any training on course in risk } \\
\text { management }\end{array}$ & 285 & 1 & 5 & 1.98 & 1.091 \\
\hline Overall Mean & & & & 2.14 & \\
\hline
\end{tabular}

\subsection{Risk Management Practices of SME Owners}

The result as presented in table 4.4 show the descriptive statistics of the risk management strategy construct. The level of risk management items was done using 5-point Likert scale from strongly disagree through to strongly agree. In light of this, the overall mean value is compared with the individual item means. The result shows the overall mean score $[\mathrm{M}=2.55$ and considering the 13 items used to measure this indicator from respondents of SME business owners, 7 items obtained mean scores of [ $>$ or $=2.55]$, whilst 6 items obtained mean values less than the overall mean score. By implication, the results suggest the adoption of poor risk management strategies among SME owners is impeding on the operational survival of their businesses. The environment in which SME businesses operate, is continually evolving and, as a result, the risks it faces are continually changing hence risk management strategies must be practiced (Idemobi, 2012). A sound system of risk management therefore depends on a thorough and regular risk management strategy which seem to be lacking in the sector (Kagwathi et al, 2014). 
Table 4.4: Risk Strategies

N Mean SD

\section{Risk Identification}

Do SME business scan the environment for the prese

$285 \quad 2.90 \quad 1.184$

Does business owners identify the sources of risks their business is facing

The business owner uses tools to identify risk (brainstorming, checklist, observation)

\section{Risk Assessment}

Does SME owners prioritize significant risks

Does SME owner use analytical tools to assess risk

The owners consult people on issues pertaining to risk (auditors, accountants)

\section{Risk Response}

Managers avoid business activities that are risk

The business has an insurance to cover business operations

The business owner has internal controls in place

\section{Risk Monitoring}

Business owners have policies in place to monitor risk

SME business owners compare the risk situation in their business with the plan

Follow - up procedures are effective at response to risk and control assessment and taking actions to correct deviations

\subsection{Correlation Analysis}

The correlations between pairs of independent variables were within the acceptable threshold. The findings in table 4.6, revealed that the independent variables used in the study are not highly correlated. The highest observed positive correlation between risk assessment and risk identification is 0.797 . In line with Greene (2008), the threshold for this test is 0.8 or -0.8 and notably, all the correlation coefficients of the independent and control variables are within the threshold -0.8 to 0.8 . This concludes that the independent variables do not suffer severe multicollinearity and not pose a problem to the model findings and subsequent inferences. 


\section{Al Macrothink}

Enterprise Risk Management

ISSN 1937-7916

2022, Vol. 7, No. 1

The correlations analysis in table 7 is conducted to examine the strength of the relationship between the dependent variables (SMEP) and independent variables (RI, RA, RR, RM). The research findings show that all the variables are positively related to each other. This indicates that an increase in any of the risk management practices have a positive impact on profitability and performance of SME businesses. In line with the findings, Sax \& Torp (2015) posited that proper risk management practices impact on performance positively.

Table 4.6: Correlation results

\begin{tabular}{|c|c|c|c|c|c|}
\hline Constructs & SMEP & RI & RA & $\mathrm{RR}$ & $\mathrm{RM}$ \\
\hline SMEP & 1 & & & & \\
\hline RI & 0.545 & 1 & & & \\
\hline RA & 0.599 & $.797 * *$ & 1 & & \\
\hline $\mathrm{RR}$ & $0.684 * *$ & $.649 * *$ & $.593 * *$ & 1 & \\
\hline RM & 0.406 & $.578 * *$ & $.697 * *$ & $.479 * *$ & 1 \\
\hline
\end{tabular}

The results of the regression analysis in table 4.7 shows that about $82.1 \%$ of variance in SMEP is accounted for by the independent variables (RI, RA, RR, RM). Considering the regression results show that RI predict SMEP significantly indicated as $[\beta=.346, p<0.10]$. This suggests that RI exert significant effects on SMEP in SME businesses. In addition, RA predicted SMEP positively indicated as $[\beta=.892, \mathrm{p}<0.10]$. This suggests significant effect of RI on SMEP. Moreover, RR predicted SMEP in a positive as indicated as $[\beta=.491, p<$ 0.10]. Finally, the result shows that enhanced risk monitoring (RM) predicted effective SMEP positively indicated as $[\beta=865, \mathrm{p}<0.10]$. In line with the findings Afolabi (2018) indicated that performance is improved if proper risk management approach is adopted by management. Meidell and Kaarbøe (2017) also posited that efficiency of risk management lead to high survival rate of SME businesses beyond the first 5 years. The regression for the SME Performance model is; SME Performance $=10.875+0.345 \mathrm{RI}+0.892 \mathrm{RA}+0.491 \mathrm{RR}+$ $0.865 \mathrm{RM}$ 


\section{Table 4.7: Regression results}

\begin{tabular}{lc}
\hline Variables & Model $(\beta)$ \\
\hline Constant & 10.875 \\
RI & $.346(4.343)^{* * *}$ \\
RA & $.892(7.781)^{* * *}$ \\
RR & $.491(-2.214)^{* * *}$ \\
RM & $.865(24.101)^{* * *}$ \\
Model Summary & \\
R-square & 0.821 \\
F Statistics & $654.121 * * *$ \\
\hline
\end{tabular}

Notes: SMEP: SME Performance; **. significant at the 0.01 level (2-tailed). *. significant at the 0.05 level (2-tailed). ***. significant at the 0.10 level (2-tailed).

\section{Discussion}

The study revealed that majority of SME business owners have low level education. The SME sector is dominated by semi-literates mostly senior high school leavers. The study revealed that majority of SME managers or business owners have low level of knowledge with respect identification of risk. 58\% were not sure whether their business is exposed to risk and 34\% were not aware of the risks their business faces. The average mean value of 2.14 suggested that SME business owners and managers do not have proper training on risk management, cannot properly identify risk that affects their business and do not consider risks as critical to the business.

The study further examined how risk management practices affects the performance of SMEs and the study revealed a positive relationship between SME Performance and risk management practices. This indicates that an increase in risk management practices positively affects performance. The regression analysis showed significant level for all the independent variables. The study therefore found a positive significant relationship between SME performance and risk management practices (risk identification, risk assessment, risk response, risk treatment and risk monitoring)

\subsection{Conclusion}

According to the findings, the low educational level of respondents helped to conclude that risk management is not widely practiced in SME businesses. Risk management practices are not well practiced in SME business because the SME owners possess low level of knowledge in the areas of identifying, assessing, treating and monitoring key operational 
risks. The positive relationship between risk management practices and performance revealed is indicative that the proper practise of risk management by SME managers or owners influences performance. The significant relationship between the dependent variable (performance) and independent (risk management practices) provided the conclusion that the more SME businesses improve on their risk management, the more they improve upon their performance. The study recommends an improvement in risk management knowledge for SME business owners and managers. The government should take adequate steps to provide risk management support for SMEs sectors to prevent SME businesses from collapse within the first 5 years of their existence. The study recommends SME businesses to put in place systems that enable the documentation of their business operations. SME owners should be willing to pay for professional services that would help the business to save cost in the long run. The study recommends further research into the effect of Enterprise risk management (ERM) on SME Performance.

\section{References}

Adeyele, J. S., \& Osemene, O. F. (2018). Small and medium enterprises' risk exposures and mitigation approaches in Nigeria. The Journal of Entrepreneurial Finance (AEF), 20 (1), $21-42$.

Aduko, J., (2011). General insurance, a tool for managing business risks: A case study of SMEs in the Tamale Metropolis. Masters Dissertation: Kwame Nkrumah University of science and Technology, Ghana. Retrieved July 15 2014, from http://www.lib.umi.com.

Afolabi, T.S., (2018). Effect of Claims Payments on Profitability in the Nigerian Insurance Industry. Advances in Social Sciences Research Journal, 5(4), 94-101.

Agwu, M. O. \& Emeti, C. I. (2014). Issues, challenges and prospects of small and medium scale enterprises (SMEs) in Port-Hacourt city, Nigeria. European Journal of Sustainable Development, 3(1), 101-114. Doi: 10.14207/ejsd.2014. v.3n1p101.

Alrashidi, A., \& Bakeel, O. (2012). The impact of operational risk management on the financial development and economic growth: a case study of Saudi SME companies. European Journal of Business and Management, 4(5),251-268.

Ansong, A. (2013). Risk management as a conduit of effective corporate governance and financial performance of small and medium scale enterprises. Risk Management, 3(8), 352-678.

Ariyo, D. (2008). Small Firms are the Backbone of the Nigerian Economy. Retrieved online from http:/www.africaeconomyanalysis.org, August 24, 2012.

Aruwa, S.A.S. (2004). Financing Options for Small and Medium-Scale Enterprises in Nigeria. The Nigerian. Journal of Accounting and Research, Department of Accounting, Ahmadu Bello University, Zaria, 1(2),

Azende, T. (2012). Risk Management and Insurance of Small and Medium Scale Enterprises 
(SMEs) in Nigeria. International Journal of Finance and Accounting, 1(1), 8-17.

Azende, T. (2012). Risk Management and Insurance of Small and Medium Scale Enterprises (SMEs) in Nigeria. International Journal of Finance and Accounting, 1(1), 8-17.

Belás, J., Bartoš, P., Habánik, J., Novák, P. (2014), Significant Attributes of the Business Environment in Small and Medium-Sized Enterprises. Economics and Sociology, 7(3), 22-39. DOI: $10.14254 / 2071-789 X .2014 / 7-3 / 2$

Belás, J., Bartoš, P., Ključnikov, A., \& Doležal, J. (2015). Risk perception differences between micro, small and medium enterprises. Journal of International Studies, 8 (3), 20-30. DOI: $10.14254 / 2071-8330.2015 / 8-3 / 2$

Bilal, S., Muhammad, A.N. and Abdul, J. K. (2012). Firm's characteristics and capital structure: A panel data analysis of Pakistan's insurance sector. African Journal of Business Management. 6(14), 4939-4947.

Blazy, R., and Weill, L., (2013). Why do Banks Ask for Collateral in SME lending?Applied Financial Economics, 23(13),1109-1122.

Boniface, U. and Ibe, I. G. (2012). Enterprise Risk Management and Performance of Nigeria’s Brewery Industry. Developing Country Studies, 2(10), 60-67.

Crovini, C., Santoro, G., \& Ossola, G. (2020). Rethinking risk management in entrepreneurial SMEs: towards the integration with the decision-making process. Management Decision, 10(6),331-345. doi:10.1108/md-10-2019-1402

Eniola, A. A., Entenbang, H. \& Sakariyau, O. B. (2015). Small and medium scale business performance in Nigeria: Challenges faced from an intellectual capital perspective. International Journal, 5(1), 212-245.

Eyiah, D.K (2015). Assessment of Risk Management Practice of Small and Medium Scale Enterprises in The Secondi-Takoradi Metropolis, Ghana. Unpublished Masters Dissertation, Department of Accounting and finance, University of Cape Coast.

Ferreira, A., Lima, P., Crema, M., \& Verbano, C. (2019). Risk Management in SMEs: a systematic literature review and future directions. European Management Journal. 5(3), 20-38. doi:10.1016/j.emj.2019.06.005

Florio C. \& Leoni G. (2017). Enterprise risk management and firm performance: The Italian case. British Accounting Review, 49(1), 56-74

Frazer, L. (2012). The effect of internal control on the operating activities of small restaurants. Journal of Business \& Economics Research, 10(6), 361-374.

Gatzert, N., \& Martin, M. (2015). Determinants and value of enterprise risk management: empirical evidence from the literature. Risk Management and Insurance Review, 18(1), 29-53.

Grace, M. F., Leverty, J. T., Phillips, R. D., \& Shimpi, P. (2015). The value of investing in 
enterprise risk management. Journal of Risk and Insurance, 82(2), 289-316.

Idemobi, E.I. (2012). The problem of sustaining the growth of small and medium enterprises in a typical Sub-Saharan African context. African Journal of Social Sciences, 2, 15-24.

Kagwathi, G. S., Kamau, J. N., Njau, M. M., Kamau, S. M., Darya, G., Maheshwari, S., \& Tiwari, S. K. (2014). Risks faced and mitigation strategies employed by small and medium enterprises in Nairobi, Kenya. Journal of risk and insurance, 5(1), 83-88

Khan, M.J., Hussain, D. and Mehmood, W. (2016). Why do firms adopt enterprise risk management (ERM)? Empirical evidence from France. Management Decision, 54(8), 1886-1907.

Kinyua, E., Ogollah, K. \&Mburu, D. K. (2015). Effect of risk management strategies on project performance of small and medium information communication technology enterprises in Nairobi, Kenya. International Journal of Economics, Commerce and Management, 2(3), $1-30$.

Li, Q., Wu, Y., Ojiako, U., Marshall, A., \& Chipulu, M. (2014). Enterprise risk management and firm value within China's insurance industry: Original Research.Acta Commercii, 14(1), $1-10$.

Lukianchuk, G. (2015). The impact of enterprise risk management on firm performance of small and medium enterprises. European Scientific Journal, 11(13), 37-52

Maseko,N. \& Manyani, O.(2011). Accounting Practices of SMEs in Zimbabwe: An Investigative Study of Record Keeping for Performance Measurement (Acase Study of Bindura). Journal of Accounting and Taxation, 3(8), 171- 181.

Meidell, A. and Kaarbøe, K. (2017), How the Enterprise Risk Management Function Influences Decision-Making in the Organization - A Field Study of a Large, Global Oil and Gas Company. British Accounting Review, 49 (1), 39-55

Muhammad, I. S. \& Amber O. (2011). The Essence of Enterprise Risk Management in Today's Business Enterprises in Developed and Developing Nations. European Journal of Social Sciences, 25(4), 515- 524.

National Bureau of Statistics (2010). Annual Abstract of Statistics. Federal Republic of Nigeria. SME, business risks and sustainability in Nigeria. European Journal of Business and Social Sciences, 2(9), 1-10.

Owduri, S. (2012). Framework for Sustainability Entrepreneurship for Small and Medium Enterprises (SMEs) in An Emerging Economy. World Journal of Management, 4, 51-66.

Pallant, J. (2011). Survival manual: A step by step guide to data analysis using SPSS (4th ed.). Sydney, Australia: Allen and Unwin.

Panigrahi, A.K. (2012). Risk management in Micro, Small and Medium Enterprises (MSMEs) in India: A Critical Appraisal. Asia Pacific Journal of Marketing \& Management Review, $1(4)$. 


\section{Macrothink}

Enterprise Risk Management

ISSN 1937-7916

2022, Vol. 7, No. 1

Petroni, G., Venturini K., \& Verbano C. (2012). Open innovation and new issues in R \& D organization and personnel management. The International Journal of Human Resource Management, 23(1), 147-173.

Santoro, G., Mazzoleni, A., Quaglia, R. and Solima, L. (2019). Does age matter? The impact of SMEs age on the relationship between knowledge sourcing strategy and internationalization. Journal of Business Research, 5 (1). 1-9.

Sax, J. and Torp, S.S. (2015). Speak up! Enhancing risk performance with enterprise risk management, leadership style and employee voice. Management Decision, 53(7),1452-1468

Simota, J., Tupa, J., \& Steiner, F. (2018). Risk Management to Enhance Performance in the Construction SME Sector; Theory and Case Study. Risk Management Treatise for Engineering Practitioners, 2(1), 1-15. doi:10.5772/intechopen.68798

Small and Medium Enterprises Development Agency of Nigeria (SMEDAN) (2013). SMEDAN and National Bureau of Statistics collaborative survey: Selected findings. Retrieved from http://www.nigerianstat.gov.ng

Smit, Y. and Watkins, J.A. (2012). A literature Review of Small and Medium Enterprises (SME) Risk Management Practices in South Africa. Africa Journal of Business Management, 6,6324-6330.

Verbano, C. and Turra, F. (2010). A human factors and reliability approach to clinical risk management: Evidences from Italian cases. Safety Science, 48(59), 625-39.

Verbano, C., \& Venturini, K. (2011). Development Paths of Risk Management: Approaches, Methods and Fields of Application. Journal of Risk Research, 14(5-6), 519 - 550.

Yakob, S., Hafizuddin-Syah, B.A.M., Yakob, R., \& Raziff, N.A.M. (2019). The Effect of Enterprise Risk Management Practice on SME Performance. The South East Asian Journal of Management, 13(2), 151-169.

\section{Copyright Disclaimer}

Copyright for this article is retained by the author(s), with first publication rights granted to the journal.

This is an open-access article distributed under the terms and conditions of the Creative Commons Attribution license (http://creativecommons.org/licenses/by/4.0/). 